\title{
Replacement of Postharvest Moisture Loss by Recharging and Its Effect on Subsequent Moisture Loss during Short-term Storage of Carrots
}

\author{
Solomon I. Shibairo ${ }^{1}$ and Mahesh K. Upadhyaya ${ }^{2}$ \\ Department of Plant Science, University of British Columbia, Vancouver, B.C. V6T 1Z4, Canada \\ Peter M.A. Toivonen ${ }^{3}$ \\ Summerland Research Centre, Agriculture and Agri-Food Canada, Summerland, B.C. VOH IZO, Canada
}

\begin{abstract}
Adpitional index words. abrading, Daucus carota L., shelf life
Abstract. Replacing postharvest moisture loss in carrots (Daucus carota L., 'Caro-choice') by single and repeated recharging (rehydration in water) treatments, interaction between the duration of recharging and temperature during recharging, and the effects of these treatments on moisture loss during subsequent short-term storage were studied. Carrot mass gain increased with increase in duration of single recharging treatments. Carrots that had lost $2.96 \%$ of their mass during storage at $13{ }^{\circ} \mathrm{C}$ and $35 \%$ relative humidity regained as much as $83 \%$ of the mass during recharging for 12 hours. Longer rechargings had little additional effect. Recharging at $13{ }^{\circ} \mathrm{C}$ and $26^{\circ} \mathrm{C}$ was more effective at replacing water than at $0^{\circ} \mathrm{C}$. The rate of moisture loss (percent per day) during subsequent storage was not affected by recharging duration and temperature during recharging. With repeated recharging every 3.5 days, increase in recharging duration up to 9 hours increased carrot mass gain. Most of the mass gain occurred following 0 to 7 days of storage. These treatments, however, did not affect the rate of moisture loss during subsequent storage. These results suggest that the beneficial effect of recharging on carrot quality is due to replacement of the lost moisture and not to a decrease in moisture loss during storage following recharging. Abrading increased mass loss in non-recharged carrots and increased mass gain during recharging. Recharging should be explored as an option to improve the shelf life of carrots.
\end{abstract}

Quality and storage life of fruits and vegetables are reduced by moisture loss, physiological breakdown, and decay. Carrots stored at high temperatures tend to wilt, have poor appearance, and hence a short shelf life. Controlled atmosphere during storage as well as chemical treatments have been used to slow down physiological changes and decay in carrots. Wills et al. (1979) reported that lowering the $\mathrm{O}_{2}$ concentration or increasing the $\mathrm{CO}_{2}$ concentration during storage reduced respiration and physiological breakdown of carrots. Using calcium propionate or potassium sorbate during hydrocooling has reduced postharvest development of black root rot in carrots (Punja and Gaye, 1993). However, because of consumer concern regarding use of chemicals on food, development of nonchemical means to maintain carrot quality during storage is needed.

Several methods have been used to reduce moisture loss from fruits and vegetables during storage. Refrigeration has been used extensively to slow metabolism and reduce water loss. Use of jacketed room storage and Filacell systems (Raghavan et al., 1980) increases relative humidity, which reduces moisture loss. However, these systems are expensive and not intended for the retail market.

One possible option to enhance shelf life is to replace the lost moisture by recharging (rehydration in water) carrots. It is an

Received for publication 24 Oct. 1996. Accepted for publication 27 Mar. 1997. This project was supported by the Science Council of British Columbia, British Columbia Agricultural Research Council, Brilish Columbia Coast Vegetable Coopcrative, and Natural Sciences and Engineering Research Council of Canada. Shibairo thanks the Canadian International Development Agency for a postgraduate scholarship. Use of trade names does not imply endorsement of the products named nor criticism of similar ones not named. The cost of publishing this paper was defraycd in part by the payment of page charges. Under postal regulations, this paper therefore must be hereby marked advertisement solely to indicate this fact.

${ }^{1}$ Graduate research assistant.

'Associate professor.

?Research scicntist. industry practice to wash and hydrocool carrots to remove field heat before storage, packaging, and transportation (Phan, 1987). While some reabsorption of moisture may occur during hydrocooling, because of its short duration, carrots do not fully regain their turgidity. Lentz (1966) observed that carrots that had lost $7 \%$ to $8 \%$ of their moisture regained as much as $2.6 \%$ mass after $24 \mathrm{~h}$ of immersion in ice-water and $3.0 \%$ after 1 week of storage in drained ice.

Carrots can be recharged either immediately after harvest or later during holding. It is not known whether recharging merely replenishes the lost moisture or also affects the rate of moisture loss during subsequent storage. The optimum duration and frequency of recharging, the effect of temperature during recharging, and the effect of recharging on abraded or damaged carrots have not been investigated. Therefore, our objectives were to determine the effects of 1) duration and frequency of recharging, 2) temperature during recharging, and 3) recharging of abraded carrots on root mass gain during recharging and moisture loss during subsequent short-term storage.

\section{Materials and Methods}

\section{Single recharging treatments}

Carrots ('Caro-choice'; Asgrow Seed Co., Newmarket, Ont., Canada) were grown at the Totem Park Field Station of the Univ. of British Columbia, B.C., Canada. Soil was a sandy loam with a $\mathrm{pH}$ of 6.0 and $8.9 \%$ organic matter. Fertilizers $21 \mathrm{~N}-0 \mathrm{P}-0 \mathrm{~K}, 0 \mathrm{~N}-$ $20 \mathrm{P}-0 \mathrm{~K}$, and $0 \mathrm{~N}-0 \mathrm{P}-50 \mathrm{~K}$ were broadcast to provide the recommended (British Columbia Ministry of Agriculture, Fisheries and Food, 1992) N, P, and $\mathrm{K}$ rates of $70,8.7$, and $62.2 \mathrm{~kg} \cdot \mathrm{ha}$ ! respectively, and incorporated by raking before seeding. Nitrogen at $40 \mathrm{~kg} \cdot \mathrm{ha}^{-1}$ was top-dressed 2 months after planting.

Carrots were grown in a randomized complete-block design 
replicated four times. Each replication consisted of a $2 \times 5$-m plot with five rows $0.35 \mathrm{~m}$ apart. Carrots were seeded on 15 May 1993 and on 17 May 1994 using a Heistair-Stanhay S 870 precision seeder (FMC Corp., Burlington, Ont., Canada). Seedlings were thinned to 60 to 80 plants/meter row length 3 weeks after planting. Overhead irrigation was used to supplement rainfall.

Carrots were hand-harvested from the middle three rows $175 \mathrm{~d}$ after sowing, placed into polyethylene bags, transported to the laboratory at the Univ. of British Columbia $(<1 \mathrm{~km})$, washed in cold water, and blotted with paper towels. Uniformly selected carrots were subjected to the following treatments.

EFfect of recharging duration. A randomized completeblock design with three replications of five carrots each was used. Carrots were weighed, allowed to lose moisture for $3.5 \mathrm{~d}$ by storing in plastic bags perforated with holes $18.4 \mathrm{~mm}$ in diameter at $13^{\circ} \mathrm{C}$ and $35 \%$ relative humidity $(\mathrm{RH})$, and then recharged for $0,3,6,9$, 12 , or $15 \mathrm{~h}$. Recharging was achieved by completely submerging carrots in water in $0.30 \times 0.21 \times 0.07-\mathrm{m}$ plastic trays at $22 \pm 2^{\circ} \mathrm{C}$. Carrots were blotted dry and reweighed. Preliminary studies

Table 1. Effect of recharging duration on mass gain during recharging and on the rate of moisture loss during subsequent storage at $13^{\circ} \mathrm{C}$ and $35 \%$ relative humidity $(\mathrm{RH})$.

\begin{tabular}{lcc}
\hline $\begin{array}{l}\text { Recharging } \\
(\mathrm{h})^{\mathrm{z}}\end{array}$ & $\begin{array}{c}\text { Mass gain during } \\
\text { recharging }(\%)\end{array}$ & $\begin{array}{c}\text { Mass loss following } \\
\text { recharging }(\% / \text { day })\end{array}$ \\
\hline 0 & --- & 1.19 \\
3 & 1.08 & 0.85 \\
6 & 1.44 & 0.96 \\
9 & 2.00 & 0.71 \\
12 & 2.45 & 0.91 \\
15 & 2.51 & 0.70 \\
SE & 0.14 & 0.06 \\
Significance & $\mathrm{L}, \mathrm{Q}^{y}$ & NS
\end{tabular}

The carrots were recharged for different durations on day 3.5 and stored at $13{ }^{\circ} \mathrm{C}$ and $35 \% \mathrm{RH}$ for $21 \mathrm{~d}$.

${ }^{\mathrm{y}} \mathrm{L}, \mathrm{Q}$, and NS are linear, quadratic, and not significant at $P \leq 0.05$, respectively; $\mathrm{SE}=$ the $\mathrm{SE}$ of the mean.

Table 2. Mass gain during recharging and the rate of moisture loss from carrots recharged at various temperatures for different durations after $3.5 \mathrm{~d}$ of storage at $13^{\circ} \mathrm{C}$ and $35 \%$ relative humidity (RH).

\begin{tabular}{lccc}
\hline $\begin{array}{l}\text { Recharging } \\
\text { temperalure }\left({ }^{\circ} \mathrm{C}\right)\end{array}$ & $\begin{array}{c}\text { Duration of } \\
\text { recharging }(\mathrm{h})\end{array}$ & $\begin{array}{c}\text { Mass gain during } \\
\text { recharging }(\%)\end{array}$ & $\begin{array}{c}\text { Mass loss following } \\
\text { recharging (\%/day) }\end{array}$ \\
\hline 0 & 3 & 0.70 & 1.21 \\
& 6 & 0.94 & 1.19 \\
SE & 9 & 0.99 & 0.91 \\
Significance & & 0.02 & 0.34 \\
13 & 3 & $\mathbf{L}^{\mathrm{z}}$ & $\mathrm{NS}$ \\
& 6 & 0.84 & 1.11 \\
& 9 & 1.68 & 0.95 \\
SE & & 1.82 & 1.03 \\
Significance & & 0.03 & 0.28 \\
26 & 3 & $\mathrm{~L}, \mathrm{Q}$ & $\mathrm{NS}$ \\
& 6 & 1.08 & 1.07 \\
& 9 & 1.60 & 1.1 .5 \\
SE & & 2.14 & 1.00 \\
Significance & & 0.06 & 0.28 \\
Duration of recharging & & $\mathrm{L}, \mathrm{Q}$ & $\mathrm{NS}$ \\
Temperature of recharging & & $*$ & $\mathrm{NS}$ \\
Duration $\times$ temperature & & $*$ & $\mathrm{NS}$ \\
\end{tabular}

${ }^{\mathrm{Z}} \mathrm{L}, \mathrm{Q},{ }^{*}$ and NS are linear, quadratic, and nonsignificant at $P \leq 0.05$, respectively. $\mathrm{SF}=\mathrm{SF}$ of the mean. Carrots were stored at $13^{\circ} \mathrm{C}$ and $35 \% \mathrm{RH}$ after receiving rccharging treatments for $2 \mathrm{l}$ from the start of the experiment. showed that carrots absorb moisture most readily between 3.5 and $7 \mathrm{~d}$ under these conditions.

EFFEct of TEMPERATURE AND DURATION OF RECHARging. A randomized complete-block design with three replications of five carrots each in a factorial arrangement with three recharging water temperatures $\left(0,13\right.$, and $\left.26^{\circ} \mathrm{C}\right)$ and three recharging durations $(3$, 6 , and $9 \mathrm{~h}$ ) was used. Recharging was achieved by dipping carrots in water in $0.30 \times 0.21 \times 0.07-\mathrm{m}$ plastic trays at these temperatures. After recharging and reweighing, the carrots were incubated in perforated plastic bags as previously described at $13{ }^{\circ} \mathrm{C}$ and $35 \%$ $\mathrm{RH}$; their mass was monitored every $3.5 \mathrm{~d}$ for $21 \mathrm{~d}$.

Mass gain upon recharging was analyzed using a general linear model (Wilkinson et al., 1992). Single-degree polynomial contrasts were fitted using the means of various treatments for trend analysis using SYSTAT statistical software (Wilkinson et al., 1992). Slopes of the percent mass loss curves were analyzed to determine the rate of moisture loss during short-term storage following recharging. Although only results of the experiments conducted in 1994 are presented, similar results were obtained in 1993.

\section{Repeated recharging treatments}

For this study, carrots were grown on a commercial field (Hing Sing Farm, Cloverdale, B.C., Canada). The soil had a pH of 5.3 and was $48.9 \%$ organic matter. The field was under lettuce during the previous 2 years. Fertilizer $(5 \mathrm{~N}-12 \mathrm{P}-16 \mathrm{~K})$ was broadcast to provide the recommended (British Columbia Ministry of Agriculture, Fisheries and Food, 1992) rates of N, P, and K $(45,23.6$, and $59.8 \mathrm{~kg} \cdot \mathrm{ha}^{-1}$, respectively) and were incorporated by raking into the soil before seeding. Carrot seeds ( 'Caro-choice'; Asgrow Seed Co., Kalamazoo, Mich.) were sown on 28 Apr. 1994 and on 19 May 1995 using a precision seeder (model S 870); Hestair Stanhay, FMC Corp., Burlington, Ont., Canada) on (0.1-m-high raised beds on $1.7-\mathrm{m}$ centers. Three rows $(0.35 \mathrm{~m}$ apart) with three lines $(10 \mathrm{~mm}$ apart) in each row were seeded per bed. Paraquat (preemergent) and linuron (postemergent) were used for weed control, and cypermethrin, parathion, and diazinon were used for insect control. Overhead irrigation was used as necessary to supplement rainfall.

The carrots were harvested from a $1.32 \mathrm{~m}$ wide $\times 10 \mathrm{~m}$ long area 90 (1994) and $105 \mathrm{~d}(1995)$ after sowing. For studying the effect of abrading, carrots were harvested 125 (1994) and $120 \mathrm{~d}$ (1995) after sowing. Carrots were put in polyethylene bags, taken to the Univ. of British Columbia (52 $\mathrm{km}$ away), washed to remove dirl, and blotted dry with paper towels. Uniformly selected carrots were subjected to the following treatments.

EFFECTSOI DCRATIION AND FREQUENCY OF RECHARGING. Carrots (five per treatment) were weighed, stored at $13{ }^{\circ} \mathrm{C}$ and $35 \%$ RH as previously described, and recharged (at $22 \pm 2{ }^{\circ} \mathrm{C}$ ) every 3.5 $\mathrm{d}$ for $0,3,6$ or $9 \mathrm{~h}$ to determine the 
effect of duration of recharging. In a separate experiment, carrots were recharged for $6 \mathrm{~h}$ every $3.5,7$, or $14 \mathrm{~d}$ to determine the effects of frequency of recharging. The non-recharged carrots served as controls.

EFFeCT OF RECHARGING ON ABRADED CARRots. Six carrots per treatment were abraded by placing a cardboard template over their surface $(0 \%, 20 \%$, and $40 \%$ of area) and scrubbing three times with a nylon nail brush using a moderate force. The carrots then were divided into two lots of three carrots each. One lot was recharged for $6 \mathrm{~h}$ every $3.5 \mathrm{~d}$, and the other served as a non-recharged control.

Recharging was achieved by dipping carrots in water at $22 \pm 2$ ${ }^{\circ} \mathrm{C}$ as previously described. Carrots were weighed before and after recharging and were incubated in perforated plastic bags at $13{ }^{\circ} \mathrm{C}$ at $35 \% \mathrm{RH}$ as previously described for $21 \mathrm{~d}$. The carrots were weighed and their color visually evaluated every $3.5 \mathrm{~d}$.

The duration and frequency of recharging treatments were laid out in a completely randomized design with four replications. A completely randomized design in a split-plot arrangement was used in the recharging study with abraded carrots. The recharging conditions were arranged as the main plots and the abrading levels as subplots.

Repeated measures analysis was performed on the mass gain following recharging and on the apparent percent mass loss (AML; mass loss without correction for the mass gained during recharging) data in all the experiments using the SYSTAT statistical program (Wilkinson et al., 1992). Slope analysis was performed on mass loss data to quantify the rate of moisture loss during storage after recharging. In the frequency of recharging experiments, the means were separated by Fisher's least significant difference procedure. Although only the results of the experiments conducted in 1995 are presented, similar results were obtained in 1994.

\section{Results}

\section{Single recharging of carrots}

Effect of recharging duration. Mass gain, expressed as percent of root fresh mass, increased with the duration of recharging (Table 1). The relationship between mass gain and duration of recharging was linear and quadratic. However, the rate of increase in mass gain decreased with recharging duration longer than $12 \mathrm{~h}$. The effect of recharging on the rate of moisture loss during subsequent storage for $21 \mathrm{~d}$ was not significant.

TEMPERATURE AND RECHARGING DURATION. The effects of temperature $\times$ duration of recharging interaction on carrot mass gain during recharging was not significant. Mass gain increased with increase in recharging duration at all recharging temperatures (Table 2). It also increased with increase in the temperature of recharging water from 0 to $13{ }^{\circ} \mathrm{C}$ or $26{ }^{\circ} \mathrm{C}$ at all recharging durations. The rate of mass loss over a subsequent 21 -d storage was not affected by duration of recharging or temperature of the recharging water (Table 2 ).

\section{Repeated recharging}

EFFeCt OF DURATION AND FREQUENCY OF RECHARGING. Increase in duration of recharging increased water uptake by carrots at all times of recharging except on day 0 (Fig. 1A). The percent mass gain was greatest when carrots were recharged on the day 3.5 of storage at $13{ }^{\circ} \mathrm{C}$ and $35 \% \mathrm{RH}$; it decreased thereafter in all treatments. With the exception of days 14 and 17.5 , the rate of mass gain was lower in carrots recharged for 9 and $6 \mathrm{~h}$ compared to $3 \mathrm{~h}$ (Fig. 1B).
The recharging duration affected $\mathrm{AML}$ of carrots during incubation at $13{ }^{\circ} \mathrm{C}$ at $35 \% \mathrm{RH}$ (Fig. 1C). Carrots recharged for $9 \mathrm{~h}$ had the lowest AML followed by 6 and $3 \mathrm{~h}$. The non-recharged carrots lost the most mass. The rate of increase in AML during $17.5 \mathrm{~d}$ of incubation in carrots recharged for $9 \mathrm{~h}$ was about one third $(0.4 \%$ per day) that of the non-recharged control ( $1.2 \%$ per day). The rates of real mass loss (i.e., mass loss following correction for the mass gain during recharging) were not affected by recharging treatments (data not shown).

An increase in the duration of recharging caused browning of
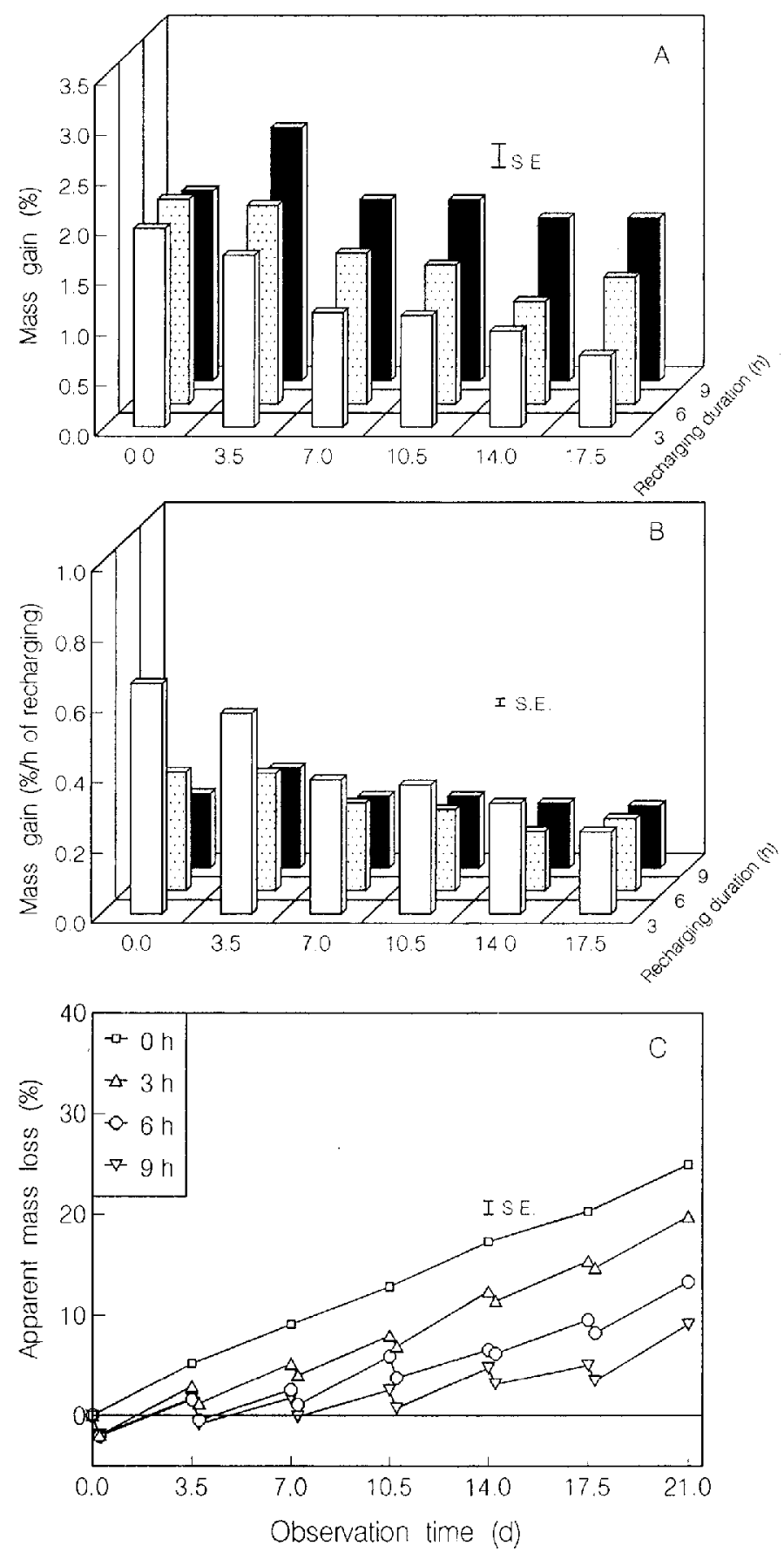

Fig. 1. (A) mass gain (percent), (B) mass gain (percent per hour of recharging) and (C) apparent mass loss (percent) of carrots recharged for different durations and stored at $13{ }^{\circ} \mathrm{C}$ and $35 \%$ relative humidity for $21 \mathrm{~d}$. The fall in apparent mass loss at each observation time in $\mathrm{C}$ indicates mass gain (percent) during recharging, which is plotted in $A$. SE $=$ overall SE of the mean. 
Table 3. Percent mass gain of carrots recharged for $6 \mathrm{~h}$ at every $3.5,7$, and $14 \mathrm{~d}$ of storage at $13{ }^{\circ} \mathrm{C}$ and $35 \%$ relative humidity $(\mathrm{RH}) .^{\mathrm{z}}$

\section{Duration}

between recharging

Observation time

\begin{tabular}{lccccc}
\cline { 2 - 6 } (d) & 3.5 & 7.0 & 10.5 & 14.0 & 17.5 \\
\hline Control & --- & --- & --- & --- & -- \\
3.5 & 2.19 & $1.79 \mathrm{a}$ & 1.37 & $1.35 \mathrm{a}$ & 1.16 \\
7.0 & --- & $2.14 \mathrm{a}$ & --- & $1.02 \mathrm{~b}$ & --- \\
14.0 & -- & --- & --- & $1.19 \mathrm{ab}$ & --- \\
$\mathrm{SE}^{2}$ & 0.15 & 0.21 & 0.04 & 0.06 & 0.07
\end{tabular}

${ }^{2}$ Carrots were storcd at $13{ }^{\circ} \mathrm{C}$ and $35 \% \mathrm{RH}$ after receiving recharging treatments. Means within a column followed by different letters are significantly different at $P \leq 0.05$ by least significant difference.

the carrot surface following $21 \mathrm{~d}$ of storage at $13{ }^{\circ} \mathrm{C}$ and $35 \% \mathrm{RH}$ (Shibairo, 1996). Carrots repeatedly recharged for $9 \mathrm{~h}$ displayed prominent darkened areas, particularly at the points of root hair attachment. The lower halves of the non-recharged controls and of the carrots repeatedly recharged for $3 \mathrm{~h}$ each time were very flaccid; they could be bent to an angle of $90^{\circ}$ without breaking. The carrots repeatedly recharged for 6 and $9 \mathrm{~h}$ were not as flexible.

When carrots were recharged repeatedly every $3.5 \mathrm{~d}$, the percent mass gain during recharging was highest on the first recharging and decreased thereafter (Table 3). Similarly the highest mass gain occurred during the first recharging on day 7 for the carrots recharged every 7 th day. Carrots first recharged on day 14 gained the least mass compared to the mass gained during the first recharging in other treatments. Mass gains during initial rechargings for carrots recharged every $3.5(2.19 \%)$ and $7 \mathrm{~d}(2.14 \%)$ were $\approx 80 \%$ greater than the mass gained by the carrots first recharged on day $14(1.19 \%)$.

The AML was highest in the control (non-recharged carrots), followed by the carrots recharged every 14 th, 7 th, and 3.5 th day (Fig. 2). However, there was no difference in the slopes of the actual mass loss (percent) curves (i.e., following correction for the mass gained during recharging) for different recharging treatments (data not shown).

EFFECT OF RECHARGING ON ABRADED CARROTS. Mass gain (percent) of abraded carrots recharged for $6 \mathrm{~h}$ every $3.5 \mathrm{~d}$ increased with increase in the level of abrading at $0,3.5,7,10.5$, and $17.5 \mathrm{~d}$ (Fig. 3A). The increase was greatest on the 7th day.

Abrading had no significant effect on AML in all treatments up to $17.5 \mathrm{~d}$ in recharged carrots (Fig. 3B). AML, however, decreased significantly $(P \leq 0.05)$ with increase in level of abrading in recharged carrots at $21 \mathrm{~d}$ of storage. In non-recharged carrots, an increase in the level of abrading increased mass loss during storage at 17.5 and $21 \mathrm{~d}$. Overall, the AML in recharged carrots was lower compared to the non-recharged carrots. There was, however, no difference in the rate of the actual mass loss (i.e., mass loss following correction for the mass gained during recharging) in different treatments.

Recharged carrots with abraded surfaces developed dark brown coloration after $10.5 \mathrm{~d}$ of storage (Shibairo, 1996). Browning increased with the degree of periderm abrading. There was a similar but less severe browning on the non-recharged carrots with $40 \%$ of their surface area abraded; non-recharged carrots with $0 \%$ and $20 \%$ of their surface area abraded did not show surface browning within $17.5 \mathrm{~d}$.

\section{Discussion}

\section{Single recharging of the carrots}

Storage under high humidity reduces moisture loss and main- tains turgidity of horticultural produce (van den Berg, 1987). Recharging by dipping produce in water may increase its turgidity, making longer storage possible. During hydrocooling, carrots are submerged in cold water for a short period, which may not provide enough time to allow reabsorption of the lost water. In this study, the carrots that had lost $2.96 \%$ of their mass regained most of their mass $(2.45 \%)$ during recharging for $12 \mathrm{~h}$. Longer rechargings had little additional effect on mass gain. Recharging did not reduce the rate of subsequent moisture loss from the recharged carrots.

Lentz (1966) reported that carrots that had lost $7 \%$ to $8 \%$ moisture regained water at $2.6 \%$ per day following immersion in ice water and $3 \%$ per week when kept in drained crushed ice. Our study clearly shows that water temperature has a significant effect on mass gain during recharging. Carrots recharged at 13 or $26^{\circ} \mathrm{C}$ for $9 \mathrm{~h}$ regained almost all their lost mass compared to only half at $0{ }^{\circ} \mathrm{C}$. Thus, 13 and $26{ }^{\circ} \mathrm{C}$ recharging temperatures are more effective at replacing water than $0{ }^{\circ} \mathrm{C}$. Whether using these temperatures introduces other problems (e.g., increase in the incidence of diseases during storage) remains to be determined.

\section{Repeated recharging of carrots}

Though water is frequently sprayed on carrots on supermarket and small store shelves, no information on the effects of repeated recharging on carrot mass gain during recharging and on moisture loss during storage of the recharged carrots is available. In this study, slopes of real mass loss (percent) curves (i.e., following the correction for mass gain during recharging) were not affected by repeated recharging treatments, suggesting that recharging did not influence the transpiration rate. The observed decrease in AML upon repeated recharging was, therefore, due to moisture absorption during recharging.

Carrots gained mass most readily if first recharged during the first $7 \mathrm{~d}$ of storage (Table 3); their capacity to absorb moisture following storage decreased progressively thereafter. We found that carrots deteriorate (membranes become leaky) and they lose

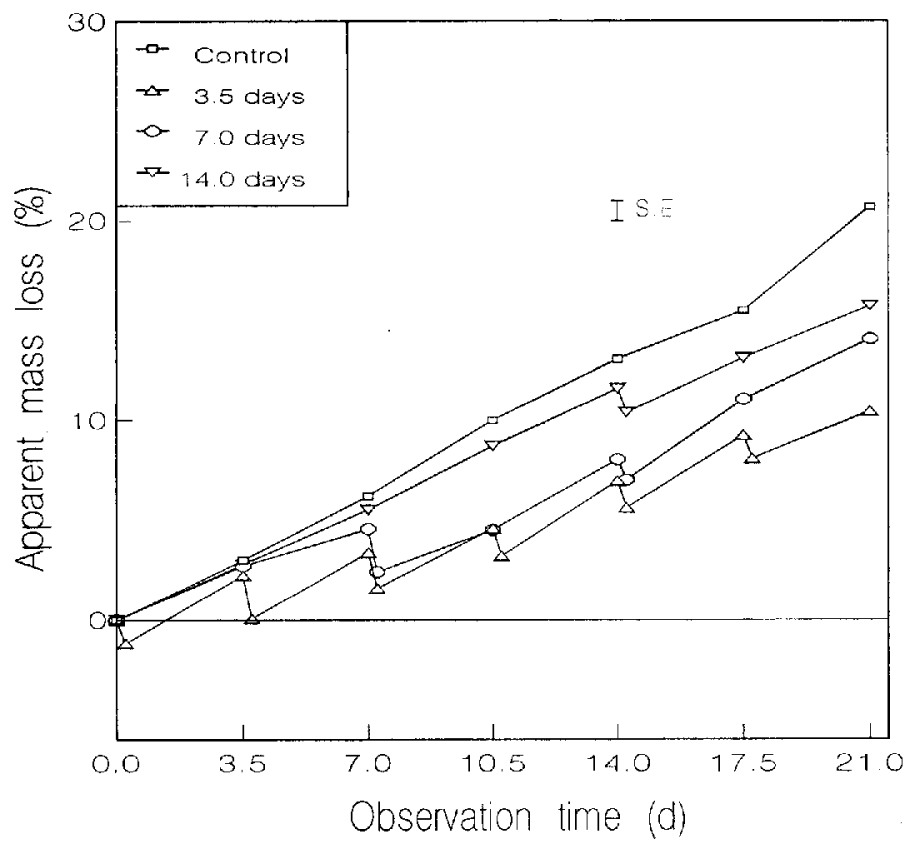

Fig. 2. Apparent mass loss (percent) of carrots recharged for 6 h every $3.5,7$, and $14 \mathrm{~d}$ and stored at $13^{\circ} \mathrm{C}$ and $35 \%$ relative humidity for $21 \mathrm{~d}$. The fall in apparent mass loss at each observation time indicales mass gain (percent) during recharging. $\mathrm{SE}=$ overall SE of the mean 

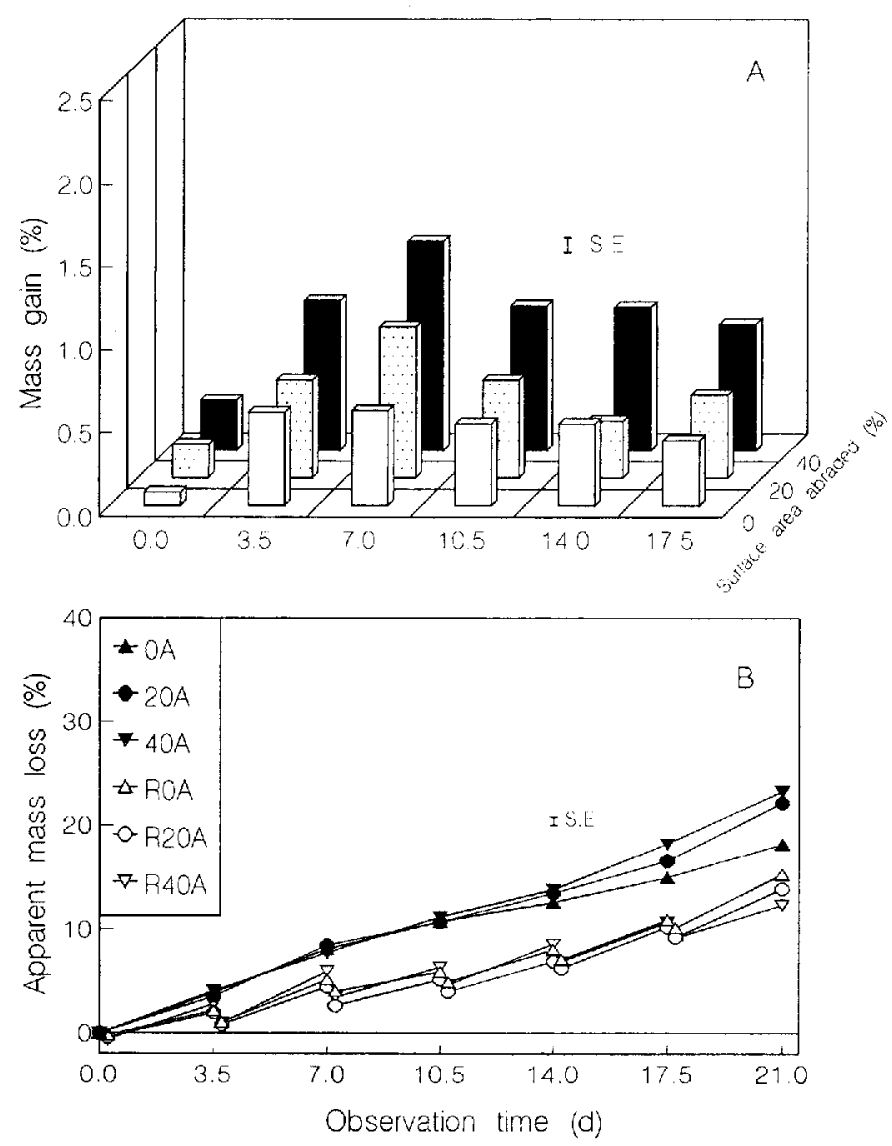

Fig. 3. Effects of recharging every $3.5 \mathrm{~d}$ for a duration of $6 \mathrm{~h}$ on (A) mass gain (percent) during recharging and (B) apparent mass loss (percent) of recharged and non-recharged abraded carrots stored at $13^{\circ} \mathrm{C}$ and $35 \%$ relative humidity for 21 $\mathrm{d}$. The fall in apparent mass loss at each observation time in $\mathbf{B}$ indicates mass gain (percent), which is plotted in A. 0A. 20A and 40A are non-recharged carrots with $0 \%, 20 \%$, and $40 \%$ of their surface area, respectively, abraded. R0A, R20A, and R $40 \mathrm{~A}$ are recharged carrots with $0 \%, 20 \%$, and $40 \%$ of their surface area, respectively, abraded before receiving recharging treatments. $\mathrm{SE}=$ overall $\mathrm{SE}$ of the mean.

the ability to maintain water potential after 1 week of storage at 13 ${ }^{\circ} \mathrm{C}$ and $35 \% \mathrm{RH}$ (Shibairo, 1996). It is possible that, as carrots start to senesce and lose membrane integrity, their ability to absorb water during recharging also may be reduced.

The storage potential of root vegetables is known to decrease with damage during harvesting (Stoll and Weichmann, 1987). In this study, an increase in the level of abrading increased mass loss during storage in non-recharged carrots. Abrading damages periderm, which is a barrier to moisture loss in carrot roots (Esau, 1940). An increase in the percentage of carrot surface area abraded increased mass gain during recharging, which in turn lowered AML. Since some abrading usually occurs during harvest and postharvest handling of carrots, this damage may improve water absorption during recharging and extend the shelf life of carrots. Excessive damage, however, will increase moisture loss and make the carrots susceptible to pathogens.

Prominent darkened areas developed around the points of root hair attachment in carrots repeatedly recharged for $9 \mathrm{~h}$. Damage caused by separation of root hairs during harvesting may be responsible for this darkening. Dorrell and Chubey (1972) suggested that any damage to the carrot root stimulates suberization and accelerates surface browning. Dry conditions during storage have caused death of the thin-walled cells (e.g., phellogen cells and the secretory cells of oil ducts in carrots) (den Outer, 1990). A layer of dead and crushed cells is formed, which decreases the carrot surface brightness. In this study browning increased with the degree of periderm abrading in recharged carrots. The poor color development would adversely affect the market value of carrots, negating the advantage gained from recharging.

In summary, recharging can replace most of the moisture lost during short-term postharvest storage. The benefit of recharging was due to increased water gain and not to decrease in the rate of moisture loss. Recharging at 13 or $26^{\circ} \mathrm{C}$ led to greater mass gain than recharging at $0^{\circ} \mathrm{C}$. Carrots benefited most from recharging within the first week following harvest. The magnitude of decrease in the AML due to recharging was higher with repeated recharging, compared to single recharging, treatments. Whether recharging of carrots is feasible under large-scale commercial conditions is beyond the scope of this work. Further technology development and feasibility studies are needed to answer this question.

\section{Literature Cited}

British Columbia Ministry of Agriculture, Fisheries and Food. 1992. Vegetable production guide for commercial growers, p. 42-47. B.C. Ministry Agr. Fisheries, and Food, B.C., Canada.

den Outer, R.W. 1990. Discolorations of carrot (Daucus carota L.) during wet chilling storage. Sci. Hort. 41:201-207.

Dorrcll, D.G. and B.B. Chubey 1972. Acceleration of enzymatic browning in carrot and parsnip roots by induced suberization. J. Amer. Hort. Sci. 97:110-111.

Esau, K. 1940. Development and anatomy of the fleshy storage organ of Daucus carota. Hilgardia 13:175-225.

Lentz, C.P. 1966. Moisture loss of carrots under refrigerated storage. Food Technol. 20:201-204.

Phan, C.T. 1987. Temperature: Effects on metabolism, p. 173-180. In: J. Weichmann (ed.). Postharvest physiology of vegetables. Marcel Dekker, New York.

Punja, Z.K. and M.-M. Gaye 1993. Influence of postharvest handling practices and dip treatments on development of black root rot on fresh market carrots. Plant Dis. 77:989-995.

Raghavan, G.S.V., R. Bovel, and M. Chayet 1980 . Storability of fresh carrots in a simulated jacketed storage. Trans. Amer. Soc. Agr. Eng. $1521-1524$.

Shibairo, S.I. 1996. A study of postharvest moisture loss in carrots (Daucus carota L.) during short term storage. PhD Thesis, Univ. of British Columbia, Vancouver, B.C., Canada.

Stoll, K. and J. Weichmann 1987. Root vegetables, p. 541-553. In: J. Weichmann (ed.). Postharvest physiology of vegetables. Marcel Dekker, New York.

van den Berg, L. 1987. Water vapour pressure, p. 203-230. In: J. Weichmann (ed.). Postharvest physiology of vegetables. Marcel Dekker, New York.

Wilkinson, L., M.A. Hill, P.J. Welma, and K.G. Birkenbeuel 1992. SYSTAT for windows: Statistics, Version 5 ed. SYSTAT, Evanston, Ill. Wills, R.B.H., P. Wimalasiri, and K.J. Scott 1979. Short pre-storage exposures to high carbon dioxide or low oxygen atmospheres for the storage of some vegetables. HortScience 14:528-530. 